San Jose State University

SJSU ScholarWorks

Master's Theses

Master's Theses and Graduate Research

2007

\title{
Habitat and herpetofauna biodversity on lower San Lorenzo River and Scotts Creek
}

Marion Katherine Blair

San Jose State University

Follow this and additional works at: https://scholarworks.sjsu.edu/etd_theses

\section{Recommended Citation}

Blair, Marion Katherine, "Habitat and herpetofauna biodversity on lower San Lorenzo River and Scotts Creek" (2007). Master's Theses. 3443.

DOI: https://doi.org/10.31979/etd.ah35-b766

https://scholarworks.sjsu.edu/etd_theses/3443

This Thesis is brought to you for free and open access by the Master's Theses and Graduate Research at SJSU ScholarWorks. It has been accepted for inclusion in Master's Theses by an authorized administrator of SJSU ScholarWorks. For more information, please contact scholarworks@sjsu.edu. 


\title{
HABITAT AND HERPETOFAUNA BIODIVERSITY ON LOWER SAN LORENZO RIVER AND SCOTTS CREEK
}

\author{
A Thesis \\ Presented to \\ The Faculty of the Department of Environmental Studies \\ San Jose State University \\ In Partial Fulfillment \\ of the Requirements for the Degree \\ Master of Science
}

by

Marion Katherine Blair

December 2007 
UMI Number: 1452074

Copyright 2007 by

Blair, Marion Katherine

All rights reserved.

\section{INFORMATION TO USERS}

The quality of this reproduction is dependent upon the quality of the copy submitted. Broken or indistinct print, colored or poor quality illustrations and photographs, print bleed-through, substandard margins, and improper alignment can adversely affect reproduction.

In the unlikely event that the author did not send a complete manuscript and there are missing pages, these will be noted. Also, if unauthorized copyright material had to be removed, a note will indicate the deletion.

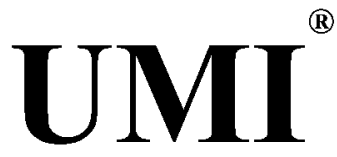

UMI Microform 1452074

Copyright 2008 by ProQuest LLC.

All rights reserved. This microform edition is protected against unauthorized copying under Title 17, United States Code.

ProQuest LLC

789 E. Eisenhower Parkway

PO Box 1346

Ann Arbor, Ml 48106-1346 
(C) 2007

Marion Katherine Blair

ALL RIGHTS RESERVED 
APPROVED FOR THE DEPARTMENT OF

ENVIRONMENTAL STUDIES

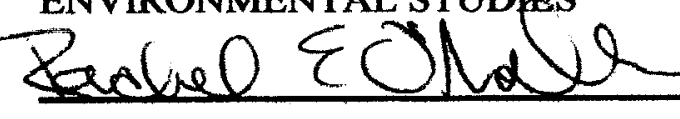

Dr. Rachel O'Malley, Committee Chair

hype Julio

Dr. Lynne Trulio, Professor

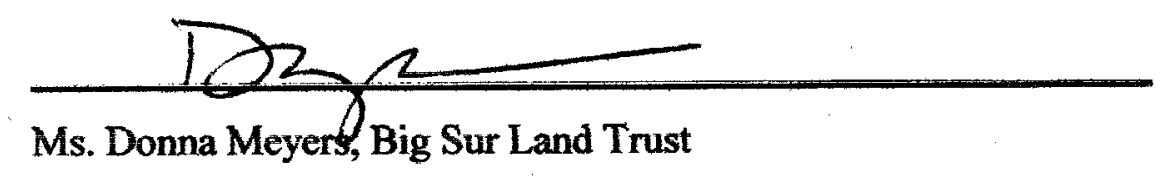

APPROVED FOR THE UNIVERSITY

Then I. Willumanon 0104/08 


\title{
ABSTRACT \\ HABITAT AND HERPETOFAUNA BIODIVERSITY ON SCOTTS CREEK AND \\ LOWER SAN LORENZO RIVER
}

\author{
by Marion K. Blair
}

Herpetofauna serve as important indicators of riparian ecosystem health due to their sensitivity to anthropogenic stressors. Increasing reptile and amphibian biodiversity is thus identified as a goal of the San Lorenzo River (SLR) restoration plan in Santa Cruz, California. No baseline data on herpetofauna abundance in the impaired estuarine river were previously available. For this study, two reaches of the target river and of a reference site, Scotts Creek, were sampled repeatedly for herpetofauna using pit-fall traps and escape cover searches. Vegetation was identified, and dominant cover was recorded. Habitat associations were assessed and sites were contrasted using ANOVA and T-tests. The SLR had more herpetofauna than expected, but numbers were markedly lower than Scotts Creek. Amphibians showed a strong affinity with native vegetation. The study underscored the importance of monitoring herpetofauna to assess restoration success and strengthened the evidence that mature native vegetation debris is critical for herpetofauna restoration. 


\section{CONTENTS}

LIST OF FIGURES $\quad \ldots \ldots \ldots \ldots \ldots \ldots \ldots \ldots \ldots \ldots \ldots \ldots \ldots \ldots \ldots \ldots$

LIST OF TABLES $\ldots \ldots \ldots \ldots \ldots \ldots \ldots \ldots \ldots \ldots \ldots \ldots \ldots \ldots \ldots \ldots \ldots \ldots$

Section

INTRODUCTION ........................... 1

BACKGROUND. ........................ 4

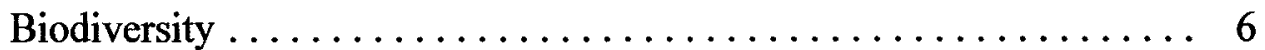

Threats to Biodiversity. .................. 7

Significance of Research to

Restoration Ecology. . . . . . . . . . . . . . . . . . 8

Ecological Significance of Research . . . . . . . . . . . 10

LITERATURE REVIEW. . . . . . . . . . . . . . . . 12

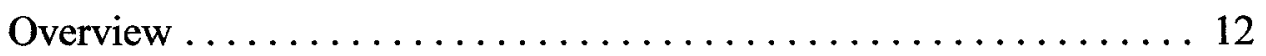

Herpetofauna Studies. . . . . . . . . . . . . . . . 13

Restoration Projects................... 17

Controversies $\ldots \ldots \ldots \ldots \ldots \ldots \ldots \ldots \ldots \ldots \ldots \ldots \ldots$

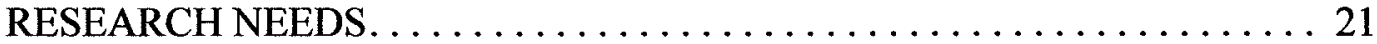

OBJECTIVES $\ldots \ldots \ldots \ldots \ldots \ldots \ldots \ldots \ldots \ldots \ldots \ldots \ldots \ldots \ldots \ldots \ldots \ldots \ldots$

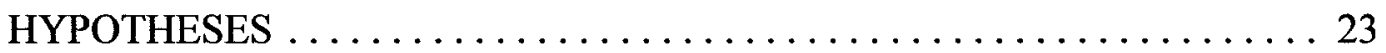

Null Hypotheses. . . . . . . . . . . . . . . . . 23

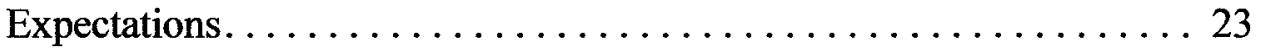


Section

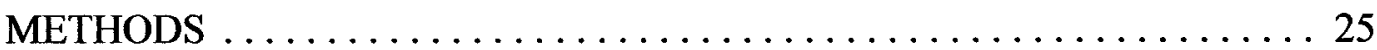

Research Sites. . . . . . . . . . . . . . . . . . 25

Scotts Creek ............................................26

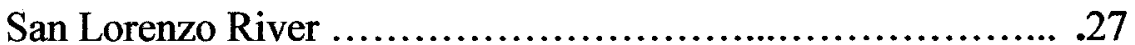

Study Design. . . . . . . . . . . . . . . . . . . 28

Sampling Design. ............................ 29

Vegetation.....................................................31

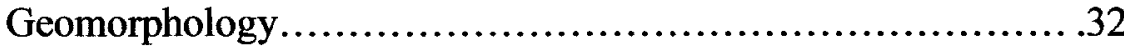

Amphibians and reptiles................................... 32

RESULTS. . . . . . . . . . . . . . . . . . . . . . . . . . 34

Qualitative: Vegetation $\ldots \ldots \ldots \ldots \ldots \ldots \ldots \ldots \ldots \ldots \ldots$

Quantitative: Herpetofauna $\ldots \ldots \ldots \ldots \ldots \ldots \ldots \ldots \ldots \ldots$

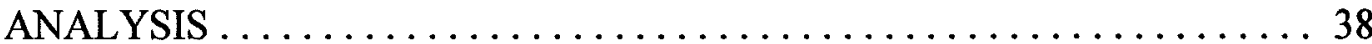

Data Analysis. . . . . . . . . . . . . . . . . . . 38

Qualitative Analysis....................... 42

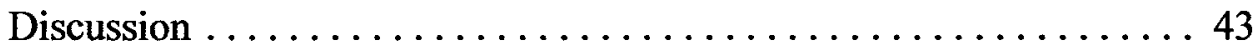

MANAGEMENT RECOMMENDATIONS $\quad \ldots \ldots \ldots \ldots \ldots \ldots \ldots \ldots \ldots$

BIBLIOGRAPHY $\ldots \ldots \ldots \ldots \ldots \ldots \ldots \ldots \ldots \ldots \ldots \ldots \ldots \ldots \ldots \ldots$ 
Appendix

A. PARTIAL SPECIES LIST OF NATIVE VEGETATION IN STUDY SITE AT SCOTTS CREEK, CALIFORNIA. . . . . . . . 54

B. PARTIAL SPECIES LIST OF NATIVE PLANTS USED IN LANDSCAPING OF SAN LORENZO RIVER LEVEES . . . . . . . .55

C. SPECIES LIST OF REPTILES AND AMPHIBIANS

OF SCOTTS CREEK. . . . . . . . . . . . . . 56 


\section{FIGURES}

Figure

1. Photograph of the San Lorenzo River in Riverine Reach (author 2002) 1

2. Quadrat Sampling Design ................... 30

3. Sample Quadrat with Drift Fence with Pit-Fall Trap Array. . . . . . . 31

4. Comparison of Amphibian Abundance between Scotts Creek and Lower San Lorenzo River. . . . . . . . . . . . . . . . . . 39

5. Relative Abundance of Riparian Vegetation between Scotts Creek and Lower San Lorenzo River. . . . . . . . . . . . 39

6. Relative Species Richness of Riparian Vegetation between Scotts Creek and Lower San Lorenzo River. . . . . . . . . . . . . . . 41

7. Relative Numbers of Amphibians Between Riverine and Transitional Reach on Scotts Creek. ................ 41 


\section{TABLES}

Table $\quad$ Page

1. Herpetofauna Identified During Two Sampling

Visits Combined, by Sampling Area $\ldots \ldots \ldots \ldots \ldots \ldots \ldots \ldots . \ldots \ldots$ 


\section{INTRODUCTION}

The San Lorenzo River is an urban stream that flows through the City of Santa Cruz, California. The lower 2.7-mile portion of the San Lorenzo River was straightened and channeled by the US Army Corps of Engineers (COE) in 1959 for flood control purposes. Only the upper reaches of the river have a semblance of their original riparian growth, with revegetation of willows and alders occurring naturally following the management strategies of the late 1950s through the 1980s (Philip Williams et al. 1989) (Figure 1). Currently, a project is underway by the City of Santa Cruz to revitalize the lower San Lorenzo River area under the auspices of the San Lorenzo Urban Renewal Plan

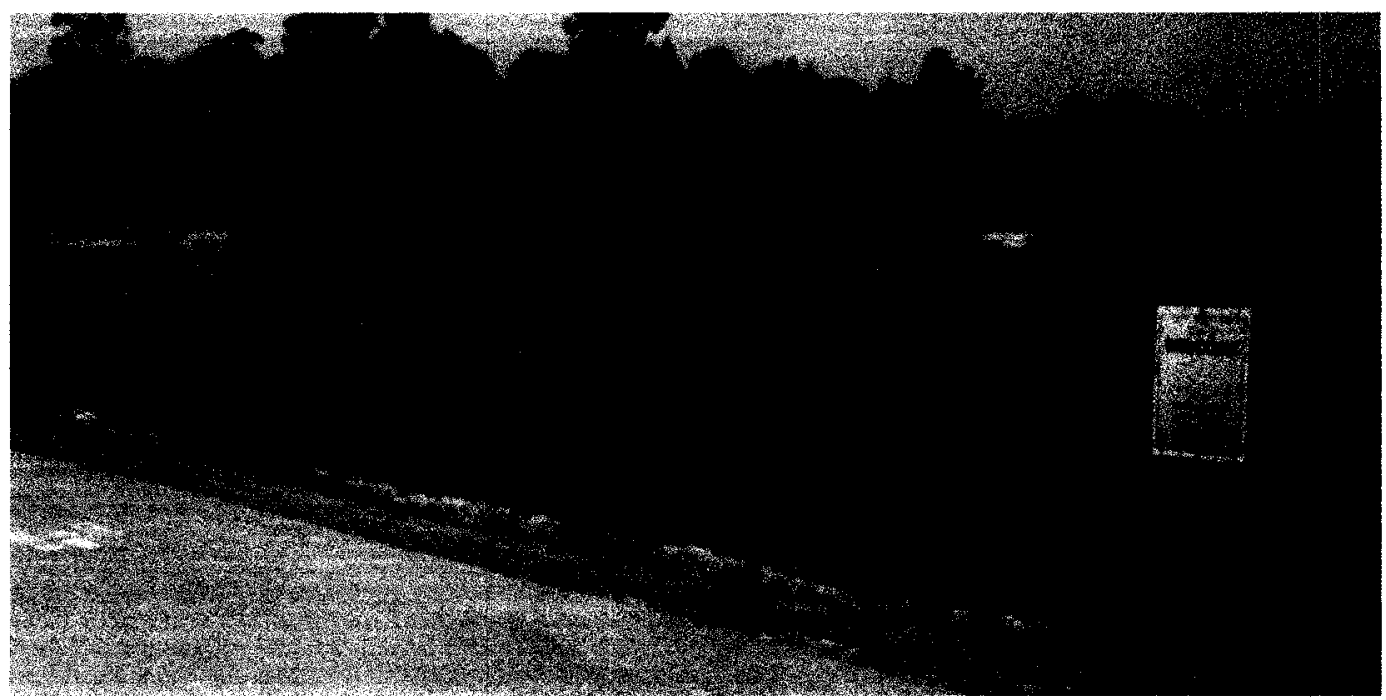

Figure 1. Photograph of the San Lorenzo River in Riverine Reach. 
(Philip Williams 2002), and to restore the river following guidelines established in the lower San Lorenzo River and Lagoon Management Plan (Swanson Hydrology et al. 2002).

The Management Plan, however, makes no indication of monitoring reptiles and amphibians as performance indicators for the restoration project. Monitoring is a necessary component of restoration projects for adaptive management purposes (Block et al. 2001, Zedler and Callaway 2000). Amphibians and aquatic reptiles are important indicators of riparian ecosystem health (Welsh and Ollivier 1998). Monitoring of populations of herpetofauna, which includes sampling studies and any correlations between human alterations to habitat, is essential to determine ecological parameters which will optimize survival of these species and contribute to general ecosystem health.

I gathered baseline information on reptiles, amphibians, and vegetation along the lower San Lorenzo River and Scotts Creek, the project's reference site, located in northern Santa Cruz County. I surveyed both sites for species richness, distribution, and abundance. By comparing these 2 sites and performing statistical analysis for habitat correlations, I provided vegetation and species target criteria for restoration of the amphibian and reptile communities on the lower San Lorenzo River.

The focal questions of this study are:

1. How do riparian vegetation conditions along the lower San Lorenzo River differ from those of the analogous reference sites at Scotts Creek?

2. Taking geomorphology into account, which vegetative features correlate to amphibian and reptile diversity and abundance at Scotts Creek? Do these same features at Scotts 
Creek predict patterns of herpetofauna distribution on the lower San Lorenzo River? The information generated by this research is useful to the San Lorenzo River Restoration Project Manager, the local Water Department, and to Regional and State Water Quality Control Boards. The results of this research have significance to County Fisheries Planners, and in application to other similar projects and agencies. This research provides valuable scientific data to herpetologists, population biologists, conservationists, and ecological restorationists. 


\section{BACKGROUND}

Wetlands, some of the most diverse and productive ecosystems in the world, are also some of the most degraded habitats due to their use by humans. In the U.S., where wetlands are now protected under various state and federal laws, an assortment of agencies manages them. The U.S. Fish and Wildlife Service (2002) justifies the habitat needs for listed species such as the Western pond turtle, Emys marmorata, and the redlegged frog, Rana aurora, both ecologically and in terms of regulatory requirements set forth by law. In California, estimates of riparian wetland loss range from $80 \%-90 \%$, and up to $99 \%$ in the Sacramento Valley (Faber and Holland 1996).

Amphibians and aquatic reptiles are good indicators of the functioning of these biologically rich ecotones (Risser 1995, Hall 1978). The risk to these amphibians and reptiles in Califonia is reflected in the fact that the California Department of Fish and Game (Jennings and Hayes 1994) has compiled a list of 48 of 80 amphibian and reptile taxa native to the State of California warranting protected status.

One significant consequence of Section 404 of the Clean Water Act is that restoration projects are frequently required as mitigation for impacts to wetlands. However, of the wildlife monitored as success criteria for riparian restoration, a review of the literature reveals few studies using the herpetofauna as target criteria. These taxa seem to have been largely ignored in restoration projects, perhaps because of their cryptic nature. As important members of the wetland community, these biota are important indicators of water quality and wetland health. Welsh and Ollivier $(1998,1118)$ state that 
the "shared vulnerability of amphibian species of their common reliance on interstitial spaces in the streambed matrix critical for life requisites . . makes amphibians more reliable indicators of potential biotic diversity in stream ecosystems that macroinvertebrates and anadromous fish."

According to the U.S. Environmental Protection Agency (2004), biological integrity is a fundamental component of water resource programs at state and federal levels. Biological integrity is defined as "the sum of balanced, integrated, and adaptive chemical, physical, and biological data" (Karr 1991). Because the biota of streams and wetlands are sensitive to all forms of pollution, biological criteria are essential to protect the integrity of the water resources (U.S. EPA 2004). The California State Water Resources Board and the Regional Water Quality Control Boards have only recently begun to apply biological assessment principles to their monitoring programs, and admit that California is "in its infancy in terms of viable biological assessment and monitoring to assess ecological condition." (CSWRB 2004).

Amphibians and reptiles play a significant role in the energy flow of ecosystems, both in terms of biomass and as links in the food web (Pough et al. 2004). As ectotherms, the amount of food they consume is very low compared to the amount of tissue they produce, yielding a high conversion efficiency compared to that of birds and mammals. A study of salamanders in the Hubbard Brook Experimental Forest in New Hampshire concluded that salamanders are quantitatively significant in the ecosystem because they represent a lot of energy. Salamanders are also capable of eating tiny invertebrates which in turn are converted to salamander biomass that is available for bird and mammal 
consumption (Pough et al. 2004). Reptiles, which can be insectivores and predators, are also functionally significant. The amphibian and reptile communities are important members of the ecosystem. They need to be included in the monitoring plans of restoration projects.

\section{Biodiversity}

Wilson (1986) provides a conceptual review of the significance of biodiversity: plants provide food, medicines, fibers, and petroleum substitutes; insects are crop pollinators, and are control agents for weeds, parasites, and other insect pests; bacteria, yeasts and other microorganisms also provide medicines and food, as well as procedures for recycling and soil restoration. Miller (2000) notes the concept of ecosystem diversity as the vehicle for maintaining biodiversity, which he describes as "nature's insurance policy against disasters" in the face of ever-changing environmental conditions. In addition to the primary sustainability needs met by the biodiversity of species, a lengthy argument could be made for functioning ecosystems as essential to the quality of human life (Cronin and Kennedy, Jr. 1997; Gore 1992).

Preserving anuran diversity is important also for their potential uses in medicine. Over 200 active alkaloids have been extracted and identified from the skin of various frogs. One such alkaloid, epibatidine, is a painkiller probably more powerful than morphine yet non-addictive (Pough et al. 2004). 
Threats to Biodiversity

According to the 2004 Global AmphibianAssessment (IUCNR 2006) nearly one third of the world's amphibian species are threatened and as many as 165 species may be extinct. The greatest losses are occuring in Latin America such as in the Cordillera of Costa Rica and Panama, Colombia, Mexico, and Ecuador. Species loss and/or decline is occurring in the American Rockies, Cascades, and Sierra Nevada, as well. Large numbers of amphibian species declines are documented for the Australian rain-forests. Growing alarm at the rates of global extinction has galvanized efforts to fill the gaps in the data worldwide (Laurance and Kareiva 2002).

Some reasons for amphibian and reptile declines appear clear enough, while others are more complex. Habitat destruction, chemical pollution, introduction of exotic species into the U.S., and harvesting by humans are undoubtedly major causes of declines in populations of amphibians and reptiles. Other suggested causes of amphibians declines are climate changes (global and local), increased ultraviolet radiation, and pathogens (Blaustein, Wake, and Sousa 1994).

Davidson et al. (2002) found high correlations between agricultural pollutants and adjacent urban land use and the decline of eight species of amphibians in California. Other ecologists have speculated that UV-B radiation and climate change have adversely affected amphibians in Central America. Studies of freshwater turtles reviewed by Bodie (2001) conclude that because the sex of of many turtles is determined by environment, they are particularly sensitive to endocrine-disrupting chemicals. Atrazine, a widely used water borne herbicide, has been implicated in gonadal abnormalities across amphibia taxa 
even where levels are well below EPA drinking water standards (Pough et al. 2004). Radiation and heavy metals have also been implicated in turtle declines, according to Bodie's review. In addition to threats from pollution, a major threat to native ranids in California are exotic aquatic species such as bullfrogs, trout, and bass due to predation pressure exerted on tadpoles (Pough et al. 2004; Jerry Smith, personal communication). Since breeding areas are a limiting factor for survival of populations these invasives are a serious threat.

\section{Significance of Research to Restoration Ecology}

Several reviews by restorationists suggest that although progress is being made in restoration ecology, knowledge of the process of restoration is young and evolving (Kentula 2000; Grayson, Chapman, and Underwood 1999; Zedler and Callaway 2000). These ecologists concur that explicit success criteria are needed in order to maximize ecological function and effective management of a watershed. In her review of success criteria for wetland restoration, Kentula (2000) recommends comprehensive planning by ecologists and other scientists using the best available information to "move current knowledge into everyday use" to provide functional success in restoration projects.

As an example, a restoration study performed by Bowers et al. (2000) in North Carolina reveals that like many organisms, specialized herpetofauna are more severely impacted by disturbance than generalists. The study reveals a need for sufficient vegetation as well as herpetofauna within a buffer zone or adjacent, undisturbed site, to 
provide a source for recolonization of the impacted riparian zones, an important factor to consider when restoring a site.

Monitoring herpetofauna in riparian restoration projects is not only essential for the success of the project, but also for the ecological information monitoring can provide. As bioindicators of environmental conditions, amphibians are "a highly suitable and extremely sensitive barometer of ecological stress" to the riparian system because of their dual life histories in both aquatic and terrestrial environments (Welsh and Ollivier 1998, 1118). Greyson, Chapman, and Underwood (1999) support the argument that species having important functional roles must be identified, and their reinstatement must be a major goal of restoration.

My study provided an important opportunity to learn more about critical mechanisms influencing successful habitat creation and ecosystem function. Specifically, performance standards for habitat restoration that measure the success of a target species' ability to be sustained or improved for the long term, need monitoring, rather than focusing on a stable habitat endpoint (Simenstad and Cordell 2000). In order to restore functional criteria, Simenstad and Cordell emphasize the importance of using assessment criteria that are "ecologically sound, adaptive, and predictive." M. J. Vander Zanden et al. (2006) emphasize the significance of food-web ecology as a functional target of restoration because of growing evidence of subtle trophic interaction playing an important role in riparian vegetation structure. The complex trophic linkages of herpetofauna could prove to be important within a broader spectrum of restoration ecology. 
In the same light, monitoring is not only essential to characterize the progress of a restoration project (Zedler and Callaway 2000), but is also a way to provide information needed to replicate restorations. This study contributes to the data on ecosystem function by the addition of monitoring studies that contribute to the science of restoration.

\section{Ecological Significance of Research}

This research has value to the science of conservation ecology in several ways. While some causes of herpetofauna declines such as habitat loss and pollution are well documented, other environmental stress factors remain poorly understood. Underscoring the complexity of isolating cause and effect, Blaustein and Wake (1995) emphasize that field work is necessary to gain more information on the potential causative factors for amphibian declines. The inventory of Scotts Creek, a minimally impacted coastal creek, as compared to the lower San Lorenzo River, adds valuable baseline information needed to gauge the ecology of herpetofauna.

Additionally, the literature reveals few long term studies of riparian herpetofauna in arid Western regions, which vary from the bottomland hardwood forests of the East with their differing stream valley dynamics (Mitsch and Gosselink 1993). Life history studies of these animals must also be long enough in duration to include complete population turnovers in order to characterize the composition of the populations, and to determine causes of mortality. Some salamanders have a 9-year life span, while Western pond turtles are known to live for over 30 years. No long term studies have been done of Western pond turtles in California, with the exception of a 7-year study (ongoing) at 
Waddell Creek by Dr. Jerry Smith (personal communication). For example, dispersal abilities of juveniles and recolonization potential following extirpation of local populations is unknown (Jennings and Hayes 1996). Therefore, detailed studies of these, as well as other species of riparian herpetofauna, are needed for their conservation. My study provides baseline data that may be used for long-term population studies. 


\section{LITERATURE REVIEW}

\section{Overview}

Habitat loss and fragmentation are widely recognized by ecologists as the primary cause for species decline and species extinction (Erlich 1986, Wilson 1986, Murphy 1986) The theory of island biogeography developed by MacArthur and Wilson (1967) serves as a useful model for how species diversity declines in relation to habitat size. Recognition for the need to protect habitat to prevent extinction is widespread (Wilcox and Murphy 1984).

While global declines in amphibians are gaining attention of scientists internationally, less attention has been given to riparian reptiles. Transitional riparian zones with their high biological productivity are critically threatened globally. The waterdependent herpetofauna of riparian systems are important indicators of wetland health because of their sensitivity to water quality and to hydrological regime. A study by Welsh and Ollivier (1998) found that these highly specialized animals, sensitive to changes in both aquatic and terrestrial environments, serve as indicator species of stream dysfunction. For example, densities of many varieties of amphibians were significantly lower in streams impacted by sediment.

Amphibians and reptiles are integral components of their communities because they serve both as predator and prey in the trophic dynamics of wetland ecosystems. They can constitute up to $40 \%$ of the biomass of riparian fauna (Pough et al. 2004). Thus the loss of these species could have significant effects on the entire ecosystem (Blaustein, 
Wake, and Sousa 1994). Amphibians are also at great risk from alterations to stream hydrology because their aquatic breeding habitat is a limiting factor.

\section{Herpetofauna Studies}

Amphibians and reptiles have been monitored in the past decade in response to varying macroenvironments and microhabitats (Gomez and Anthony 1996, Welsh and Ollivier 1998, Wilkins and Peterson 2000). Results of case studies indicate correlations between amphibian diversity and stream hydrology (Parris and McCarthy 1999), as well as correlations with age of upstream forests (Welsh and Lind 2002), integrity of riparian zones (Bowers et al. 2000), basin lithology (Wilkins and Peterson 2000), and effects of pollutants (Cole et al. 1997).

Gomez and Anthony (1996) found correlations between riparian zones with deciduous forest types and amphibian abundance. Abundance of lizards and snakes was positively correlated with upslope shrub forest types. However, some salamanders, such as the Oregon slender salamander, Batrachoseps wrighi, were also more abundant upslope. In conclusion, they argue that protection of riparian zones with a width of at least $100 \mathrm{~m}$, as well as protecting some upslope areas from timber harvest, is critical. Another study by Vesely and McComb (2001) concludes that minimum buffer strips required for anadromous fish are insufficient to protect amphibians because they require added stabilization of riparian microclimate to maintain the moist, cool conditions that are displaced at forest edges and by clearcutting. Thus, they also recommend a wider riparian zone as protected habitat. 
Welsh and Lind (2002) found that tailed frogs, Ascaphus truei are adapted to lotic microhabitats characterized by cobble and waterfalls used by tadpoles and the pools preferred by adult frogs. Older forest floors also had more of the herb cover with which A. truei are positively associated. On the other hand, the Pacific giant salamander, Dicamptodon tenebrosus, is a generalist whose distribution is more widespread on all scales throughout the region of Oregon studied. Specialization has implications in terms of habitat fragmentation due to timber harvesting and fire, because these act as isolating mechanisms.

A study of Oregon aquatic garter snakes, Thamnophis atratus hydrophilus, performed by Lind and Welsh (1994) in Northern California concludes that these aquatic snakes also require a variety of stream habitats for their life stages. As with amphibians, the complex of factors affecting the Oregon garter snake's ecology, such as foraging strategies, habitat structure, ambient temperatures, and exposure to predation, leaves them quite vulnerable to changes in their riparian habitat.

Riverine turtles (Emydidea, Emys) also require several riparian habitats to complete their life cycles, such as sandbars, channels, and backwaters, in addition to forested areas. Increased species diversity of aquatic turtles occurs with diverse geomorphology such as varied substrates, water velocities, and water depths. The Western pond turtle, Emys marmorata, which requires forest pools, is also negatively impacted by siltation. Reduced turtle populations in many regions of the U.S. are attributed to continual deposits of silts and clays (Bodie 2001). 
A study conducted by Wilkins and Peterson (2000) found that differences in basin lithology have a strong influence on the amphibian fauna. They note a tendency of basalt streams to be higher in elevation, with a more northerly aspect, wider channels, and a more cobbled substrate. Marine sediment streams, like many of those in the Central California coastal region, tend toward sandy substrate and coarse woody debris. These landscape characteristics affect different species in varying ways, and support the conclusions of others that species composition is related to habitat characteristics.

While some of the problems related to habitat loss and degradation have been studied, other causes of decline remain less well understood. A study by Drost and Fellers (1996) of the Yosemite area of California, where habitat loss and degradation can be discounted, revealed serious losses of anurans, even among the more ubiquitous species such as Hyla regilla. Though they considered that high elevation lakes may become temporarily acidified during spring now melts, Drost and Fellers suggest that chemical contaminants in the form of broad-scale pesticide drift from the San Joaquin Valley could be the culprit. Their study also supports other research that introduced bullfrogs, Rana catesbeian, and various introduced fish are major causes of amphibian declines.

Although it may be difficult to determine some of the causes, it is clear that amphibians are in serious decline. According to Block et al. (2001), long-term studies that follow populations through the species' replacement time are needed to determine if the cause of fluctuation in populations are normal or anthropogenic. However, it is unacceptable to do nothing until long term studies are completed because this might 
result in the loss of populations or entire species. Block expresses surprise at the lack of any long-term data for amphibian populations, and emphasizes the need to "initiate longterm monitoring programs for a broad array of amphibian species, populations, habitats, and geographic regions" (Block et al. 2001, 62).

In Santa Cruz County, California, studies of riparian herpetofauna have been limited to the California red-legged frog, Rana aurora, and the Western pond turtle, Emys maromorata, in Pescadero and Waddell Creeks (Smith 2003). According to Smith, redlegged frogs require fresh water ponds or lagoons low in salinity for breeding, as well as adequate streamside habitat for over-wintering. Pond turtles require fresh water ponds with basking areas as well as upslope areas for nesting that have a dry, southern exposure. Mori (2000) assessed the status of the California red-legged frogs, Rana aurora, in the lower San Lorenzo River by performing a literature review, reviewing map overlays for the Santa Cruz and Soquel quadrangles from the California Natural Diversity Database, consultations with local biologists and agency personnel, and on-site reconnaissance. No red-legged frogs were found. Other than one survey of the San Lorenzo River in the less disturbed riverine area upstream of the Management site (Singer 1979), no other surveys have been conducted for amphibians or reptiles by professional biologists in the lower San Lorenzo River. Clearly, more field studies of this area are needed.

While geomorphological and hydrologic data for the San Lorenzo River is available from 1982 to the present (Swanson Hydrology et al. 2002), there is no information about herpetofauna and their habitat associations. The associations of these 
fauna with their vegetative and hydrological requirements are being documented and evaluated for restoration and management purposes.

\section{Restoration Projects}

Simon (2000) provides a review of the need for using biological criteria in water resource management, emphasizing the importance of the use of these criteria as a tool for resource agencies. Karr and Chu (1999) also provide a convincing argument that biological endpoints need to be used to define river health because of their response to a large range of environmental factors. Karr's views have been endorsed by the EPA as integral to maintaing water quality standards (U.S. EPA 2004).

Bunn and Davies (2000) argue for biomonitoring approaches that will further strategies for remediation based on an understanding of the causal factors for ecosystem dysfunction. Mitsch and Wilson (1996) underscore the need for satisfactory methods for functional assessments. They note that connections need to be made between structural measures and functions, such as wildlife use. Grayson, Chapman, and Underwood (1999, 231) state that if restored wetlands are to function correctly, species having important functional roles "must be identified and an effort made to reinstate these species as a major aim of restoration."

Several reviews by restorationists suggest that though progress is being made in restoration ecology, knowledge of the process of restoration is young and evolving (Kentula 2000; Grayson, Chapman, and Underwood 1999; Zedler and Callaway 2000). They concur that success criteria need to be made explicit in order to maximize 
ecological function and effective management of a watershed. In her review of success criteria for wetland restoration, Kentula $(2000,201)$ recommends increased planning by ecologists and other scientists using the best available information to "move current knowledge into everyday use" to provide functional success in restoration projects.

Review of the literature reveals few studies using monitoring of herpetofauna as measures of success. In a monitoring program established at the restoration site of the Lower Coyote Creek Flood Control Project by the City of Santa Clara, Roessler (1999) notes that the small composition of reptile and amphibian communities may reflect several causes. Sampling methodologies might need to include nocturnal searches for amphibians. Source populations from which to recolonize the site might be absent, or the sites may be characteristic of an early successional stage of riparian habitat. If so, biological diversity could change with time. If, however, the creek corridor or adjacent lands is depauperate of source species, restoration efforts could be difficult to implement. Either way, current herpetofauna abundances provide valuable information to this project, and to others in the science of restoration ecology.

\section{Controversies}

The conservation and restoration of riparian corridors has been widely supported by ecologists to aid in the movement of organisms between refuges, to lower extinction rates and to prevent inbreeding. One of the controversies about the conservation and restoration of riparian corridors concerns the idea that riparian corridors may act as sinks where animals drawn from one core habitat may die in a corridor where mortality rates 
are high, before arriving at a second connected habitat (Simberloff et al. 1992).

Simberloff et al. argue that though riparian communities are "very threatened in some regions, their value as habitats is independent of whether they allow movement between other habitats." They also state that there is little empirical data on corridor use and that the frequently cited study performed by MacClintock, Whitcomb, and Whitcomb (1977) on corridor use by birds was not controlled. However, amphibians and some reptiles are riparian corridor dwellers, and most of their life-cycle requirements can be met there (Knutson et al. 1999).

Another controversy that appears in the literature is the challenge in setting realistic restoration goals in urban riparian systems, and obtaining commitment and involvement of local citizens for success of a project. As described by Ehrenfeld (2000), it may not be possible to restore urban wetlands with soil profiles that are extremely disturbed from channeling activities to a natural riparian ecosystem. There are factors unique to each area: in the case of the lower San Lorenzo River, extreme siltation of the river has had many significant effects (Philip Williams 2002). Additionally, the City's management of riparian vegetation as prescribed by the COE has likely had extremely damaging effects in terms of habitat value.

In addition to ecological limits, there may be limits due to conflicting values of local citizens which need to be taken into account in urban restoration "more explicitly and more fully than non-urban projects" (Ehrenfeld 2000, 255). Cairns $(2000,172)$ also supports the idea that social support is necessary because, as he says, the impetus for these restoration projects is often a sense of loss felt by the people living and working in 
or near the degraded ecosystems. Therefore, there must be a shared approach that involves people in the restoration for the ownership needed to support these projects. 


\section{RESEARCH NEEDS}

While many declines in amphibian populations have been linked to habitat loss/degradation and invasive species, other losses do not have overt explanations. Well documented declines of regional and local species appear to be recent, within the last 20 years (Drost and Fellers 1996). By collecting and analyzing data on the riparian herpetofauna of the relatively unimpaired Scotts Creek, native local populations and their habitat associations have been characterized. This information is used for comparison to remnant populations in the urban setting of the lower San Lorenzo River. From this managers and scientists can develop monitoring criteria to evaluate restoration progress of the lower San Lorenzo River. Such information can be extrapolated for application to management and restoration strategies in other settings.

A review of local natural history documents reveals only one listing of local herpetofauna found in the San Lorenzo River watershed (Singer 1979). My research adds valuable missing data on local amphibian and reptile species richness and population structures by expanding the search to north Santa Cruz County. The lower San Lorenzo River and Lagoon Management Plan states that "there is an immediate need to conduct monitoring to evaluate this hypothesis [that use of aquatic habitats by herpetofauna would be limited or non-existent] and develop a species list for herpetofauna in the restoration area" (Swanson Hydrology et al. 2002, 6-7). A recent Scotts Creek Watershed Assesment (Bulger, Smith, and Hylkema 2004) lists species of amphibians and reptiles which can be used as target criteria. 


\section{OBJECTIVES}

The objective of this study was to acess current populations of amphibians and reptiles on the lower San Lorenzo River and contrast them with populations on a relatively undisturbed stream, Scotts Creek, as a reference site. Results of this study were used to promote improved management of the lower San Lorenzo River for increased amphibian and aquatic reptile numbers and diversity.

This study addresses the following basic questions:

1. a) How do riparian vegetation conditions along the lower San Lorenzo River differ from those of the analogous reference sites at Scotts Creek, the reference model for restoration of the lower San Lorenzo River?

b) How do the species richness and abundance of reptiles and amphibians differ between Scotts Creek and the lower San Lorenzo River?

2. a) What vegetative features correlate to amphibian and reptile diversity and abundance?

b) What geomorphological features correlate to amphibian and reptile diversity and abundance?

3. Do these relationships differ between the two sites? 


\section{HYPOTHESES}

\section{Null Hypotheses}

1. a) $\mathrm{H}_{0}$ There is no significant difference in abundance and diversity of riparian vegetation on the lower San Lorenzo River and Scotts Creek.

b) $\mathrm{H}_{0}$ There is no significant difference in abundance of diversity of reptiles and amphibians on the lower San Lorenzo River and Scotts Creek.

2. a) $\mathrm{H}_{0}$ There is no relationship between vegetation diversity and richness and herpetofauna diversity and abundance.

b) $\mathrm{H}_{0}$ There is no relationship between geomorphologic features and reptile and amphibian diversity and richness.

3. $\mathrm{H}_{0}$ Different habitat associations of geomorphology and riparian vegetation on Scotts Creek do not predict herpetofauna distribution on the lower San Lorenzo River.

\section{Expectations}

Based on the natural history of the two sites, and studies of amphibian and reptile distribution and habitat correlations by Corn and Bury (1990) and Welsh and Lind (2002), I expected the following:

- Low diversity and numbers of reptiles and amphibians on the lower San Lorenzo

River other than the Pacific treefrog, Hyla regilla.

- Minimal vegetative diversity or structural complexity on the lower San Lorenzo River.

- Homogeneous substrates and soil conditions on the lower San Lorenzo River. 
- A diverse riparian zone with moderate architectural complexity on Scotts Creek.

- Some diversity and moderate abundance of herpetofauna on Scotts Creek.

- Heterogeneous stream substrate and geomorphological complexity at Scotts Creek. 


\section{METHODS}

\section{Research Sites}

Two study sites were used for this research, the lower San Lorenzo River in the City of Santa Cruz, California; and Scotts Creek in northern Santa Cruz County 90 kilometers south of San Francisco, at latitude 37 N, longitude $122 \mathrm{~W}$. The region is geologically active where the Pacific and North American plates collide, with nearby faults, the San Andreas, Zayante, and Calaveras.

The San Lorenzo River drains a watershed bordered by the uplifted granite block of Ben Lomond Mountain forming a steep ridge along the southwest side of the basin. The Zayante Fault borders a region of older tightly folded sedimentary rock to the north and east, and flat areas occur on the erodable Santa Margarita sandstone which traverses the watershed from west to east. These sandstones are significant contributors to the high level of sedimentation of the lower San Lorenzo River.

Roughly two thirds of the Scotts Creek watershed's geology is characterized by a bedrock of highly jointed and fractured Santa Cruz mudstone that protrudes at the surface. The other third is composed of granitic rock providing large areas that are extremely decomposed. Both these features of the bedrock--mudstone with high porosity and the decomposed granite--increase groundwater retention in the aquifer.

Like many streams in this North County coastal region, Scotts Creek's flood plain is located on uplifted marine terrace. Soils are a mixture of sandy loam enriched by 
alluvial deposition, and have a mineral content typical of marine sediments, such as calcium, and quartz diorite from the granite.

Both the San Lorenzo River and Scotts Creek are perennials that drain coastal mountains located in Santa Cruz County. Both are influenced by the Mediterranean climate of Western California with mild wet winters and cool dry summers. Average annual precipitation in the coastal areas of these streams is about $50 \mathrm{~cm}$, though annual averages at higher elevations in their watersheds may exceed $120 \mathrm{~cm}$ (Bulger, Smith, and Hylkema 2004).

Though these two streams differ in hydrology both as a result of the size and geology of their watersheds and engineering on the San Lorenzo, their most important differences for this research are anthropogenic. The lower San Lorenzo River has been severely modified for flood control purposes and the upper watershed is heavily populated. Scotts Creek was chosen as a reference model for the lower San Lorenzo's restoration because of its relatively pristine status and lesser human influence.

\section{Scotts Creek}

Scotts Creek is located approximately $15 \mathrm{~km}$ west and slightly north of the lower San Lorenzo River. It is a 3d-order stream that is approximately $22 \mathrm{~km}$ long, has 4 perennial tributaries, and drains a watershed of $45 \mathrm{~km}^{2}$. The creek emerges from steep forested mountains onto its small, unconfined flood plain, forming a lagoon where it discharges into the Pacific Ocean. 
The Scotts Creek watershed includes an unincorporated rural community consisting of 6 clusters of 2-4 domiciles each, mostly ranging in size from 5-20-acre parcels. Sixty-five percent of the watershed is under the ownership of four landholders. These include Lockheed-Martin, Big Creek Lumber, Pacific Materials, and a church organization. California Polytechnic Institute also owns a 1200-acre ranch that is used for scientific research and agricultural education (Rowley 2003).

The creek is relatively unimpaired as it meanders across its flood plain where it supports a typical multi-storied riparian forest of sycamore (Platanus racemosa), cottonwood (Populus fremonti), alder (Alnus oregama, A. rhombifolia), willow (Salix $s p$. ), and understory bushes such as elderberry (Sambucus sp.) and Western dogwood (Cornus sp.) (SCWA 2003) (Appendix A).

The $1 \frac{1}{2} \mathrm{~km}$ lowermost reach of Scotts Creek between the lagoon and the woodland reaches is the transitional reach, creating a robust marsh habitat. Plants characteristic of the transitional reach of Scotts Creek and the estuary are listed in Appendix B.

\section{San Lorenzo River}

The San Lorenzo River flows approximately $38 \mathrm{~km}$ from its steep forested upper watershed to its broad floodplain in the City of Santa Cruz. The river is a 2d-order stream draining a watershed of approximately $214 \mathrm{~km}$ on the northern end of the Monterey Bay, with thirteen tributaries (NOAA 1998). About 50\% of the watershed is highly developed with roads and housing. In the upper watershed septic tanks are the most common form 
of sewage treatment: for every square mile of housing there are approximately 120 septic tanks (Philip Williams 2002). The lower portion of the San Lorenzo River lies within the densely urban Santa Cruz city limits.

In 1958 the lower San Lorenzo River was denuded of vegetation and its banks were reinforced with concrete levees (Swanson Hydrology et al. 2002). For flood control purposes, the COE requires the City of Santa Cruz to remove annually in-channel vegetation throughout the river having a diameter greater than $4.5 \mathrm{~cm}$. As part of the San Lorenzo Urban Renewal Plan (Philip Williams 2002), in 2002 the outer levees of the river were landscaped with native species of plants including: alder (Alnus sp.), Box elder (Acer negundo), sycamore (Platenus racemosa), California rose (Rosa californica), and gooseberry (Ribes sp.) (Appendix B).

Typical riparian vegetation in the San Lorenzo River can be divided into three zones: estuarine, transitional, and riverine. The criteria for division are salinity and coastal influence.

\section{Study Design}

Two reaches were chosen on the lower San Lorenzo River and two on Scotts Creek. Each reach is representative of two of the three zones that have been identified for the City of Santa Cruz lower San Lorenzo River and Lagoon Management Plan: riverine and transitional (Swanson Hydrology et al. 2002). These designations are based primarily on water salinity. In selecting analogous reaches on Scotts Creek the primary criteria were salinity and coastal influence. Although attempted, it was not possible to sample the 
estuarine reach on Scotts Creek because of the high water table. Therefore, this reach was not sampled on either site.

\section{Sampling Design}

A repeated sampling through time was performed: in the early season (November 2006), mid-season (Jan 2007), and late season (March 2007). Twelve 8-by-8-m quadrats were sampled in each zone of each reach on the east bank, and 12 at both reaches on the west bank for a total of 36 samples per event at each stream. Quadrat locations were selected randomly using a random number generator for distance from channel (width) and distance from access (length) (Figure 2, next page). Following Heyer et al. (1994), sample plot corners were marked with flags, and pit fall traps were placed in the center (Figure 3). 


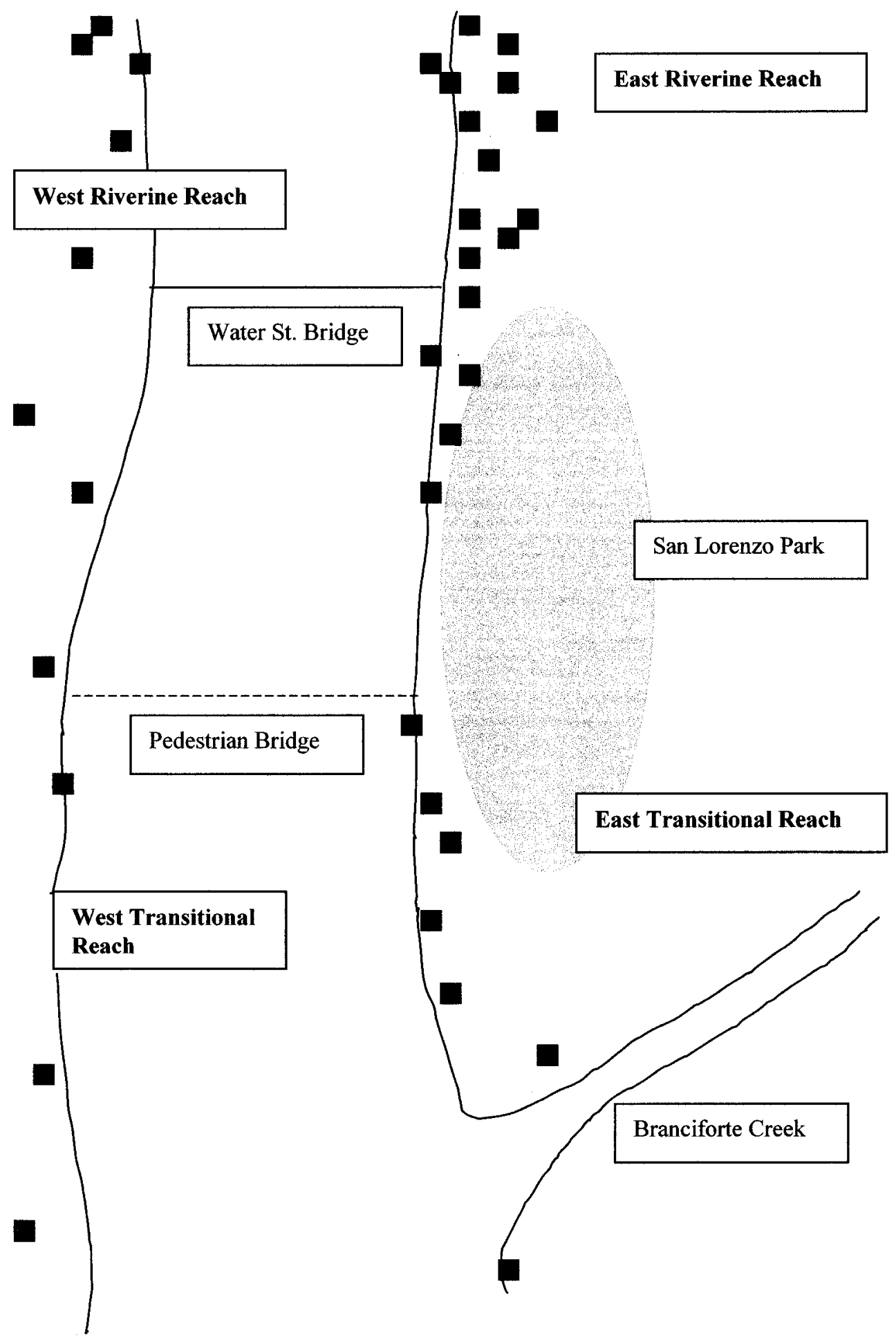

Figure 2. Quadrat sampling design (not to scale). 


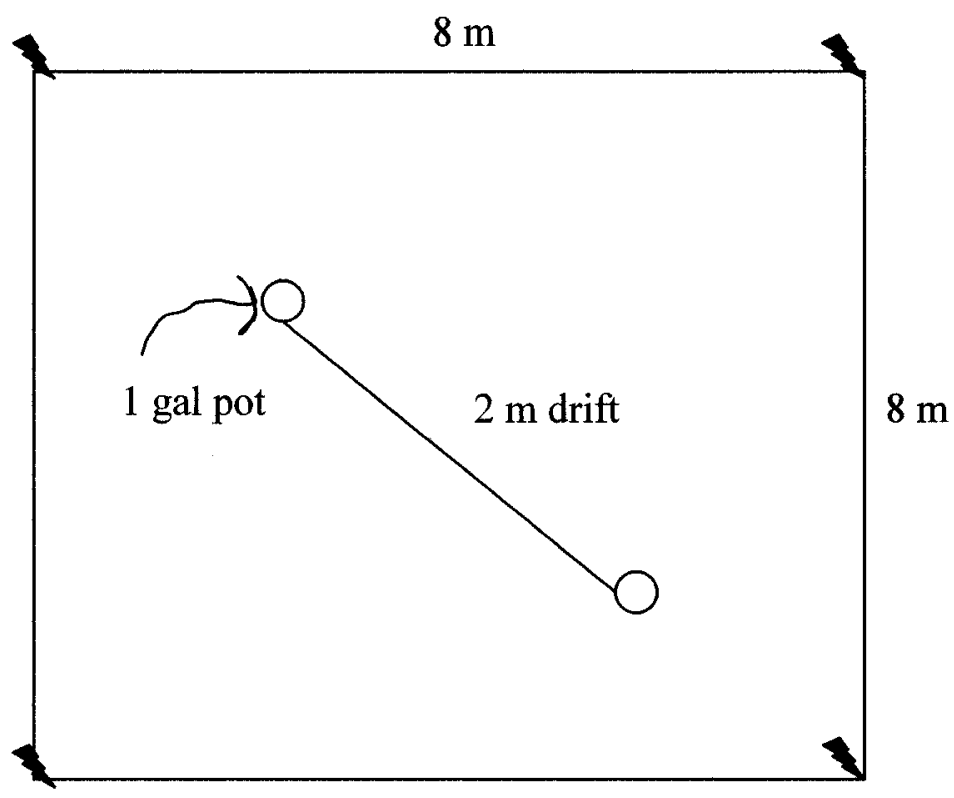

Figure 3. Sample quadrat with drift fence and pit-fall trap array.

\section{Vegetation}

Vegetation features were sampled for tree canopy, understory, and ground cover within each 8-by-8-m quadrat. Vegetative mapping of both Scotts Creek and the lower San Lorenzo River were performed using on-site visual surveys for estimated percentage cover of plant species by dominant type for each layer of vegetation (Welsh and Lind 2002). Additionally, visual inventories were performed of exposed rocks and branches (greater than $5 \mathrm{~cm}$ ), woody debris $(5-10 \mathrm{~cm}$ ), and logs (greater than $10 \mathrm{~cm}$ ) using a system of notation on a scale of 1-5, with 5 being the most abundant and largest escape cover (Wilkins and Petersen 2000). 


\section{Geomorphology}

Stream geomorphology adjacent to sample plots was characterized qualitatively for meander, stream substrate (detritus, sand, gravel, cobble), and aquatic characteristics (glide, pool, run, riffle), and recorded.

\section{Amphibians and reptiles}

In order to determine reptile and amphibian abundance and species diversity, drift fences were used in conjunction with pit-fall traps to trap animals within each sample quadrat. Each quadrat array was comprised of 2 pit-fall traps located at each end of a 1-m drift fence (Corn and Bury 1991). Drift fences were made of 1-by-2-m cloth screening held in place with a bamboo pole at either end, using metal irrigation flags for support of visual location. The pits were dug at the end of each drift fence using a trenching shovel. Into each pit a 1-gal plastic pot was inserted with a 1 -in piece of moist natural sponge within. These were covered while not in use, and the covers were raised on stilts made from the wire flags when opened to reduce loss by predation.

From levee top to levee top (lower San Lorenzo River) or the 100-m mark (Scotts Creek), working within the quadrats, all cover objects greater than $5 \mathrm{~cm}$ were moved and searched for reptiles and amphibians before replacing them (Welsh and Ollivier 1998). Amphibians and reptiles were identified to the species level and capture locations were recorded on data collection sheets.

I conducted a pilot study from March 2006 to July 2006. The final study began after the City of Santa Cruz performed its annual late summer removal of woody 
vegetation greater than $4.5-\mathrm{cm}$ diameter from the lower San Lorenzo River channel.

Visual searches were conducted 3 times at each stream, commencing in September 2006, and ending in March 2007. Searches occurred mid-morning to early afternoon, and were standardized for time spent per unit area. Search time of each quadrat was approximately 12 minutes, searching from the outside perimeter in toward the pit-fall traps. 


\title{
RESULTS
}

\author{
Qualitative: Vegetation
}

\section{San Lorenzo River}

In the riverine reach, European grasses dominate on the levee slopes, and re-vegetated native willows occur in a narrow strip along the bank full channel of the east bank. On the west bank, the grasses are the same, but the willow strip is more patchy and more bushes are found. Coyote bush (Bacharis pilularis) and Himalayan blackberry (Rubus discolor) dominate upslope, and exotic annuals such as mustard and red valerian are prolific from levee to levee. In the transitional reach along the San Lorenzo Park, a stand of large native trees, including willow (Salix sp.), alder (Alder sp.), and cottonwood (Populus sp.) dominates the

upper east bank (Appendix B). These trees shade nettles (Urtica sp.), Himalayan blackberry (Rubus discolor), and European grasses. There is very little vegetative architecture due to a lack of understory vegetation. The riparian corridor ranges in width from $2-15 \mathrm{~m}$.

\section{Scotts Creek}

Both reaches of Scotts Creek are charactarized by abundant vegetation consisting of primarily native species of rich diversity and considerable architectural complexity. The riverine reach differs from the transitional primarily in canopy species. Alders dominate in the riverine reach whereas willows dominate on the transitional reach (Appendix A). There is more abundant escape cover in the riverine reach than the transitional. The riparian buffer varies in width from $30-110 \mathrm{~m}$. It is widest in the transitional reach. The 
surrounding landscape is comprised of both active and fallow agricultural fields and cattle grazing pasture.

\section{Quantitative: Herpetofauna}

\section{San Lorenzo River}

Thirty-six quadrats were sampled 3 times, however the 1st sample time was discarded from quantitative analysis due to uneven sample sizes. One salamander (Batrachoseps attenuatus), 5 lizards representing 2 species (Sceloporous occidentalis, Elgeria coerulea) and 1 snake (Thamnophis atratus atratus) were observed or captured in the final 2 visits, as detailed in table 1 . This represents $14 \%$ of the species known to occur on this reference system for the lower San Lorenzo River (Appendix C).

\section{Scotts Creek}

Twenty-three amphibians representing 5 species (also detailed in table 1) were observed or captured within the 36 quadrats over 2 sampling times: 2 species of salamander (Ensatina eschscholzii and Batrachoseps attenuatus), the newt Taricha tarosa, and 2 species of true frog (Rana aurora and Rana boylii). This represents $24 \%$ of the species known to exist on Scotts Creek. The most abundant amphibians were the woodland salamander Ensatina eschscholtzii, which represented $50 \%$ of the amphibians observed (Appendix C). 


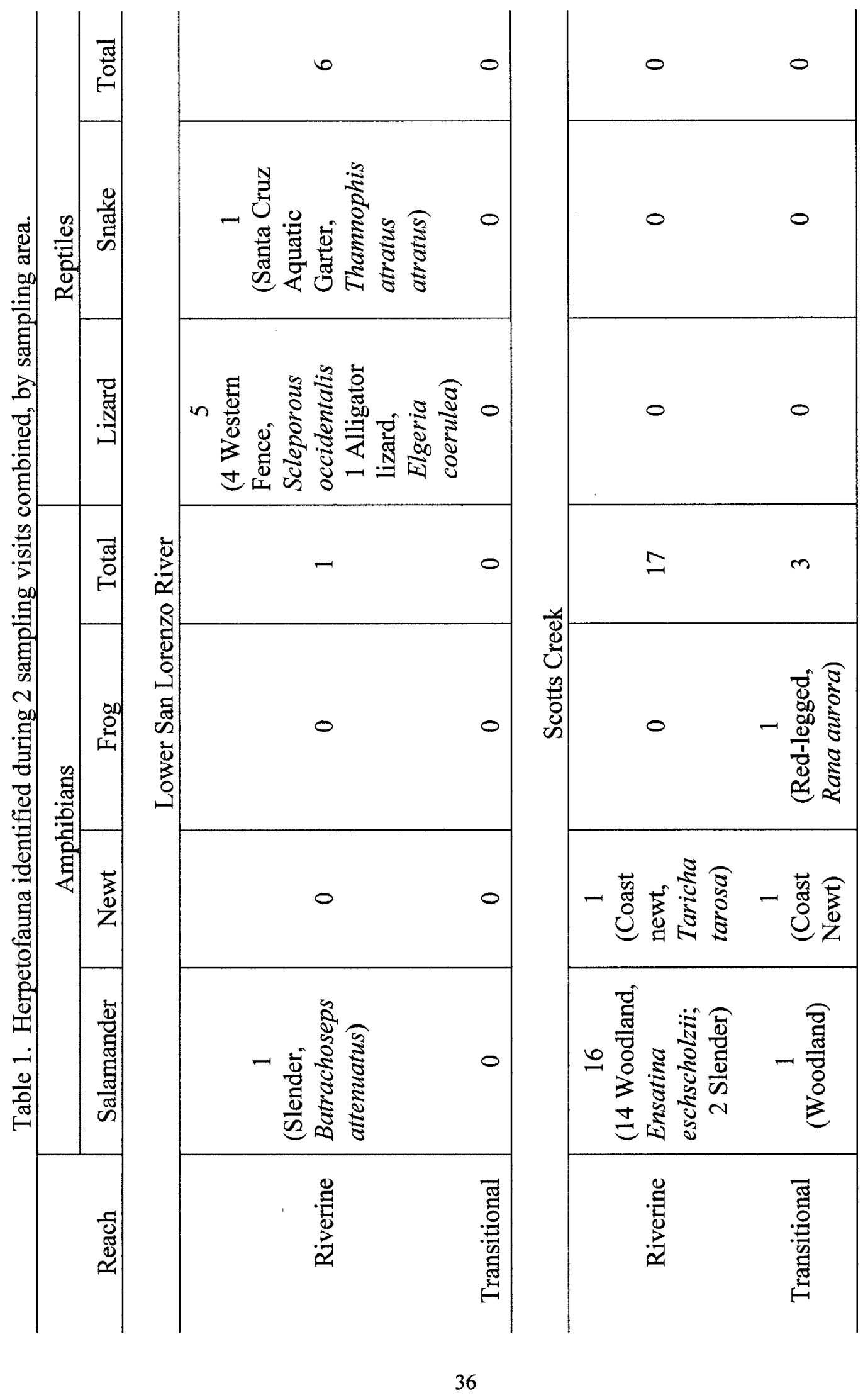


One additional California red-legged frog was trapped and a Foothill yellowlegged frog was observed within the same quadrat in the riverine reach on Scotts Creek. However, these were excluded from the quantitative analysis because of unequal sample sizes in the November sampling. I found many other red-legged frogs and Pacific tree frogs (Hyla regilla) within the east transitional reach research site where a low lying field dominated by sedges (Carex sp.) was inundated with water. 


\section{ANALYSIS}

\section{Data Analysis}

All data analysis was conducted using Systat 10 software system. Relative abundance of reptiles and amphibians was compared between the two streams using two sample T-tests (Figure 4). T-tests were also used to compare relative abundance (Figure 5) and species richness (Figure 6) of riparian vegetation between streams. Relative abundance of amphibians between reaches within Scotts Creek were compared using oneway Analysis of Variance (ANOVA) (Figure 7). Analysis of Covariance (ANCOVA) was used to correlate amphibian abundance and diversity by stream and reach with the covariate of dominant plant species.

A significant positive correlation was found for amphibian abundance by stream: where alpha $=.05, \mathrm{P}=.001$. Therefore, there are significantly greater numbers of amphibians on Scotts Creek than on the lower San Lorenzo River. In terms of relative difference in abundance of reptiles, sample size was insufficient to perform a quantitative analysis. There is a significant difference in abundance of vegetation, $\mathrm{P}=.001$, and species richness of vegetation, $\mathrm{P}=.000$ where alpha $=.05$ between Scotts Creek and the lower San Lorenzo River. The vegetation of Scotts Creek is more diverse and more abundant than that of the lower San Lorenzo River. 

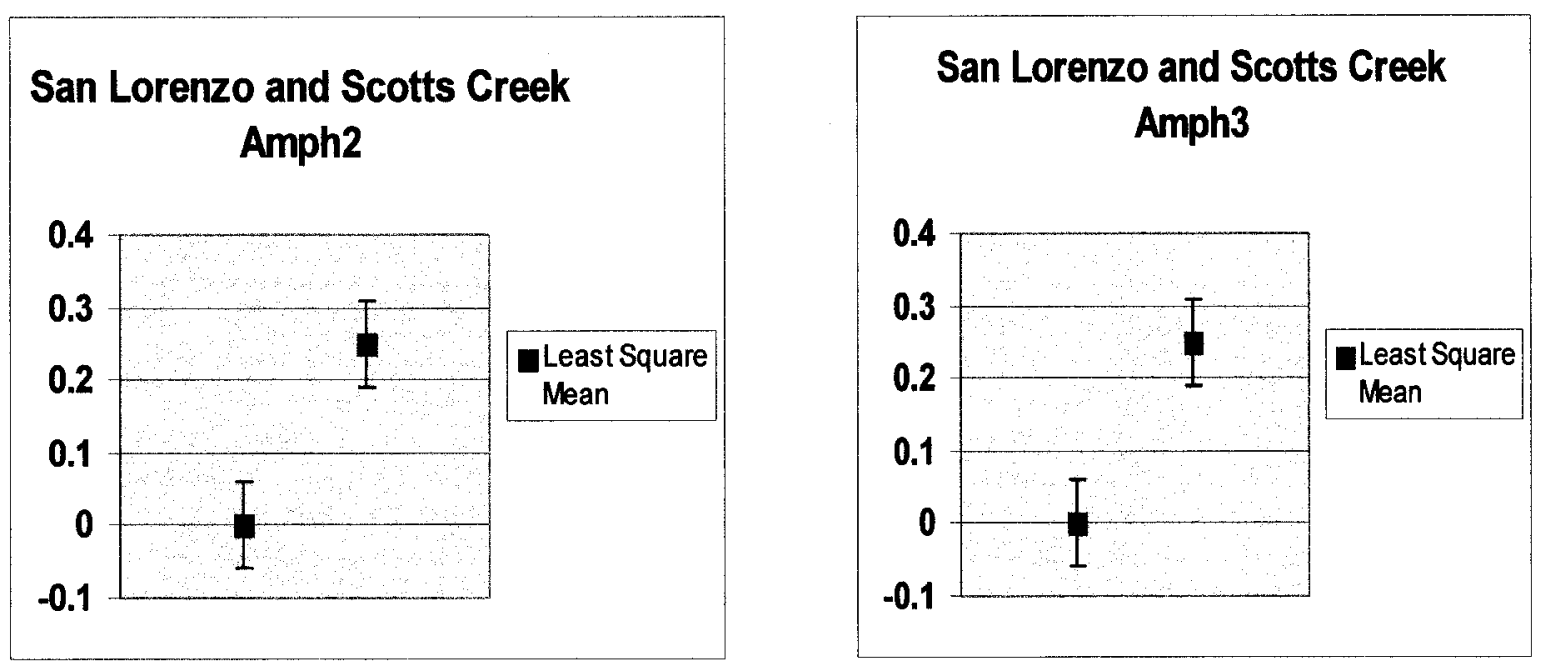

Figure 4. Comparison of amphibian abundance between Scotts Creek and the lower San Lorenzo River over 2 sample times, mid-season and late season.
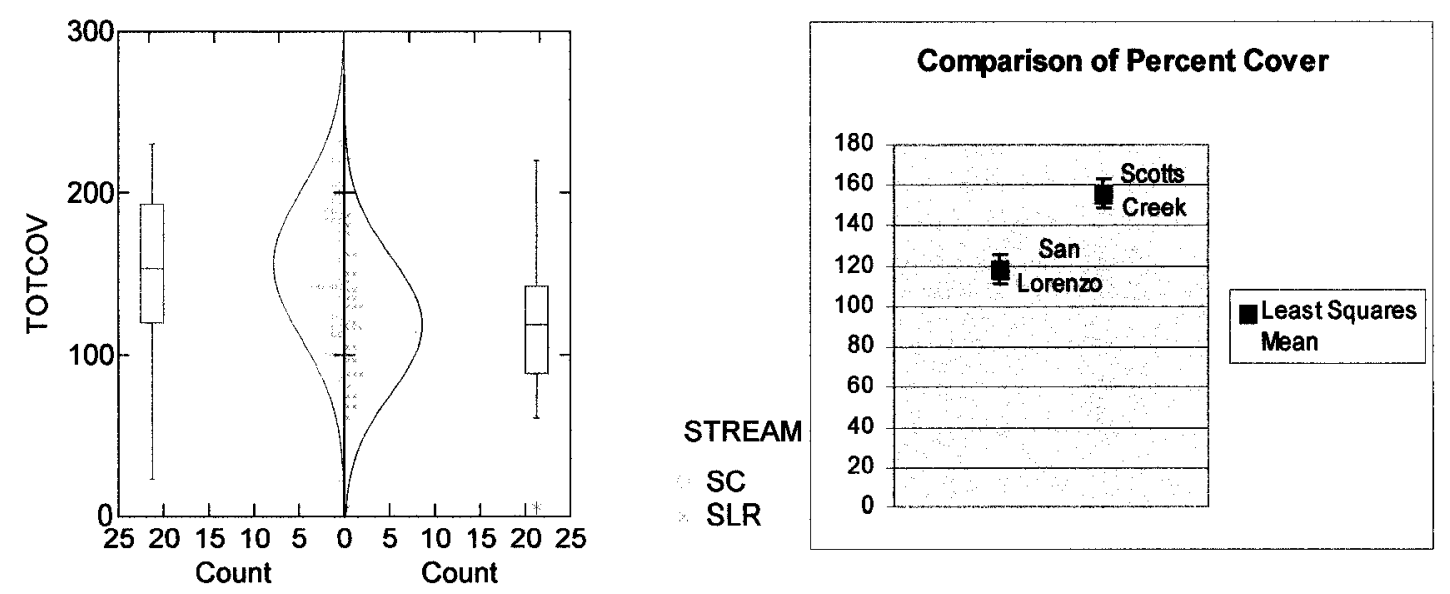

Figure 5. Relative abundance of riparian vegetation between Scotts Creek and lower San Lorenzo River. 
Differences in amphibian numbers found within each reach at Scotts Creek were analyzed by ANOVA using stream and reach as independent factors. There was a significant positive effect in the riverine reach, alpha $=.05, \mathrm{P}=.02$.

Significant positive correlations exist between stream and reach and amphibians with the added covariates: red alder (Alnus rhombifolia) $(\mathrm{P}=.005)$, native grasses/sedges/rushes (Festuca sp., Carex sp., Juncus sp.) (P=.01), elderberry (Sambucus sp.) $(\mathrm{P}=.04)$, and nettle (Urtica sp. $)(\mathrm{P}=.05)$. These plants appear to provide good cover and shade of the ground litter. Additionally, the woody debris from the alders may provide quality escape cover for salamanders. More studies are needed. 

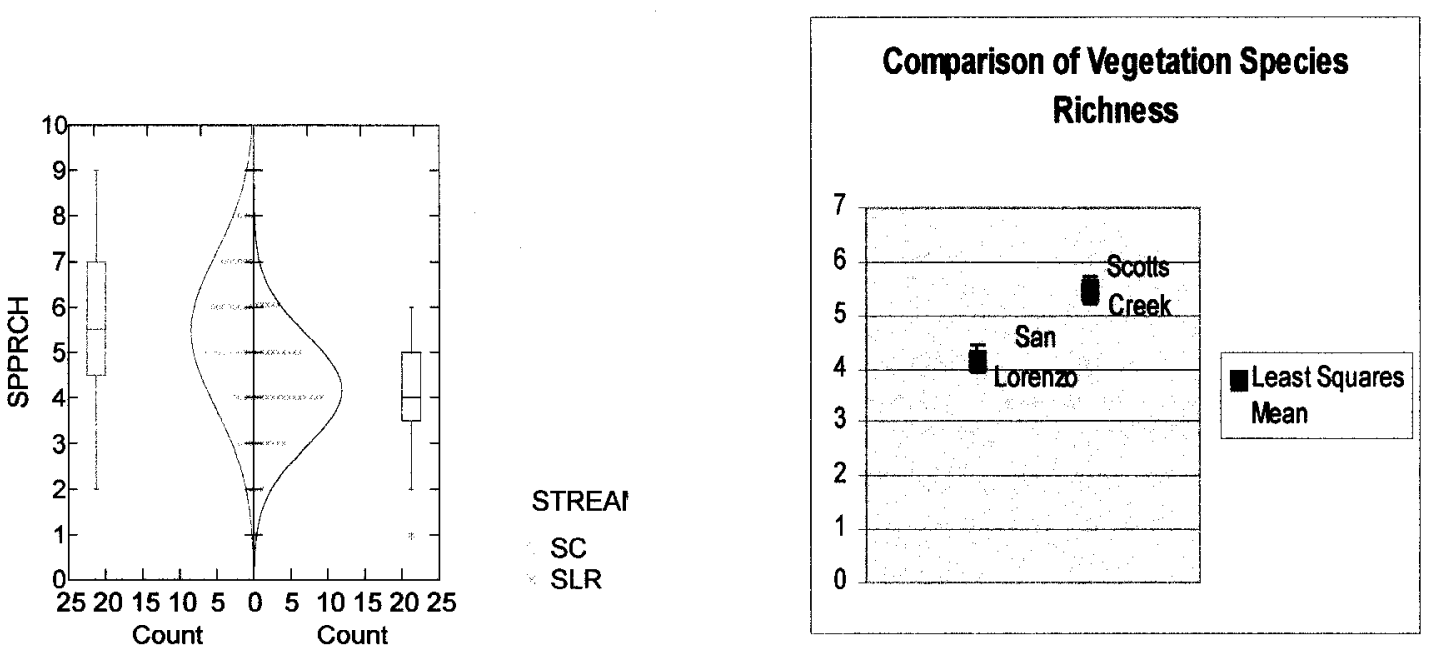

Figure 6. Relative species richness of riparian vegetation between Scotts Creek and lower San Lorenzo River.
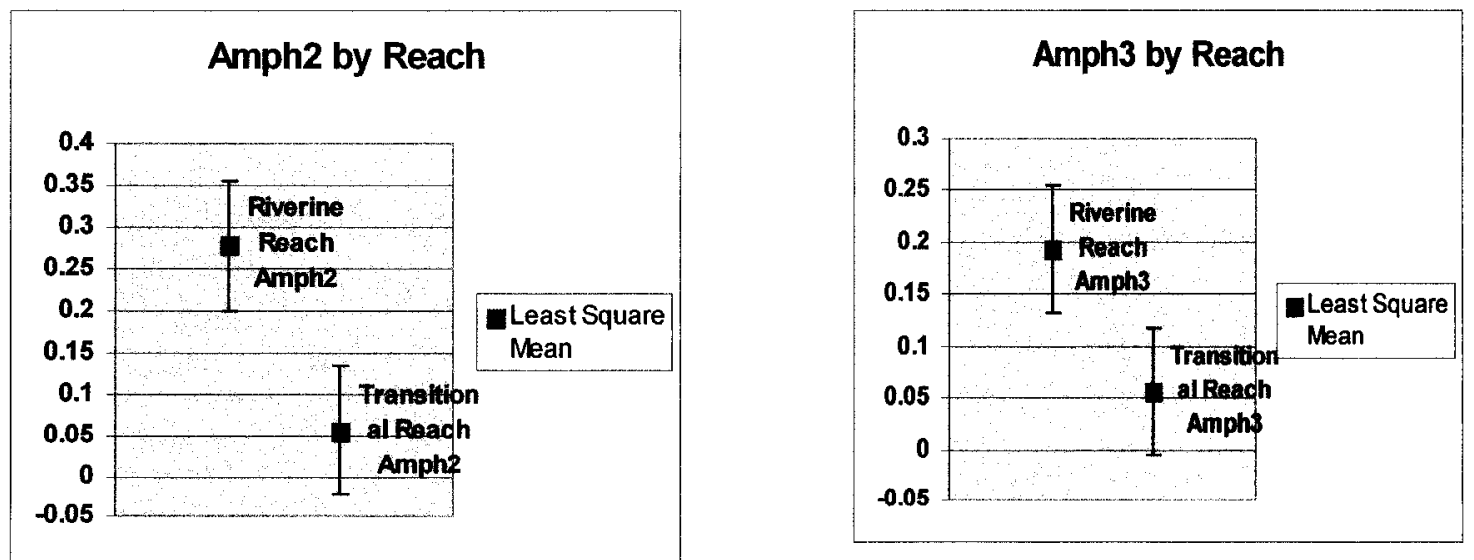

Figure 7. Relative numbers of amphibians between riverine and transitional reach on Scotts Creek. 
Qualitative Analysis

\section{Habitat associations of amphibians on Scotts Creek}

Foothill yellow legged frogs (Rana boylii) were observed on a hot August day in a narrow, shady pool. Both 1 trapped Rana aurora and 1 Rana boylii were found streamside below a backwater pool formed by large woody debris. All other frogs (Pacific tree frogs [Hyla regilla] and California red-legged frogs [Rana aurora]) were located in or near standing water in a low-lying field and along Quesaria Creek, a tributary of Scotts Creek.

\section{Habitat associations of reptiles on the San Lorenzo River}

All lizards were found upslope of the bankfull channel on rocks and stumps. The aquatic garter snakes (Thamnophis spp.) were found in the grasses adjacent to the channel. Three turtles (unable to identify accurately) were observed basking on a west-facing log along the east bank of the stream, below an alder and some of the most dense riparian willows. This area is steep which protects it from human interference. At this location the channel is bifurcated, which tends to decrease water velocity. It has a backwater-like quality in the summer, although the island is submerged and water flow is unimpeded in the winter floods, allowing increased velocity at that time. 


\section{Discussion}

Results of my analyses are consistent with other studies of habitat associations of various species of amphibians and some reptiles (Gomez and Anthony 1996, Welsh and

Ollivier 1998, Vesely and McComb 2000). There is a significant difference in abundance and diversity of amphibians between Scotts Creek and the lower San Lorenzo River probably due to human influences (Knutson et al. 1999). On the lower San Lorenzo River where siltation is extreme and suitable habitat has been lost or fragmented, significant riparian buffer, architectural complexity, and diversity of native plant species are lacking. Additionally, there are many introduced non-native plant species, which may not be conducive to the habitat needs of specialized amphibians and reptiles.

Studies indicate the need for a minimum 50-m buffer consisting of diverse harwoods for increased salamander diversity (Gomez and Anthony 1996, Knutson et al. 1999). In the San Lorenzo Park area (transitional reach) with its large riparian trees, few bushes, and no low-growing trees, little to no understory exists. The river banks are noticeably dry throughout the year compared to Scotts Creek's riparian forest. Moist, cool microhabitats are known to increase amphibian numbers and diversity (Welsh and Ollivier 1998, Veseley and McComb 2002). Little heterogeneity of habitat type-vegetative or aquatic--exists on the lower San Lorenzo because of its constrained channel and urban setting. While pools are rare in the stream hydrology of the lower San Lorenzo River, aquatic habitat on Scotts Creek is much more varied. Evidence from studies supports a positive correlation between varied aquatic habitat and increased herpetofuana numbers and diversity (Bodie and Semlitsch 1999, Smith 2003). 
Within Scotts Creek, the difference in abundance and diversity of amphibians between the riverine and transitional reaches may be due to the age of the riverine forest (Aubry and Hall 1991), or to the complexity of forest (Welsh and Lind 2002). It may be a result, as well, of a combination of factors including species of tree (mostly alder), woody debris, forest type, and width of riparian buffer (Gomez and Anthony 1996). The low number of reptiles on Scotts Creek may be due to inadequate sampling methods, as snakes could escape the pit-fall traps. However, there is also a lack of heterogeneous connecting habitat to dry upland areas on Scotts Creek that is required by many reptiles. The area surrounding the study site on Scotts Creek is homogeneous agricultural and old field habitat. The maintenance of viable populations of many species of reptiles and amphibians requires habitat heterogeneity to provide hibernating sites, breeding sites, and foraging sites (Knutson et al. 1999, Bodie 2001).

Several species of herpetofauna were found on the lower San Lorenzo River despite the common belief that no salamanders or aquatic snakes inhabit the area. The slender salamander (Batrachospes attenuatus) found under a log in a shady strip of willows streamside implies that more of this type of habitat is needed. Also, observation of 3 turtles basking on a log streamside provides a clue that woody debris provides required habitat. This is consistent with studies of freshwater turtles (Bodie and Semlitsch 1999, Smith 2003).

As many herpetofauna are nocturnal and often cryptic in coloration, visual observations alone may have been ineffective methodology. Sound recordings could be used to better identify frog communities, and night searches would have been useful. 
Some animals, snakes in particular, can escape the type of pit-fall traps used in this study, therefore traps with a one-way entry would be better suited for this study.

The lower San Lorenzo River is so seriously degraded in terms of riparian habitat that it yielded few herpetofauna. However, this is important information to obtain as baseline data, as it is scientific evidence of a lack of ecosystem health, and is useful information for setting new restoration goals and target criteria (Thom 2000).

As a flood control channel, what is feasible to restore on the lower San Lorenzo River, in reality, may be very limited. However, healthy ecosystem trajectories must not be omitted from the project design in a wholistic long term monitoring plan (Kentula 2000). Due to the complexity of multiple factors involved both in the habitat requirements of amphibians and reptiles, and the degree of habitat degredation on the San Lorenzo River, more studies are needed (Blaustein, Wake, and Sousa 1994, Ehrenfeld 2000). 


\section{MANAGEMENT RECOMMENDATIONS}

My research leads me to conclude that significantly improved management of the San Lorenzo River by the City of Santa Cruz is necessary. As there is no separate environmental entity overseeing management of the river, I recommend that the City hire trained ecologist(s) to oversee vegetative management and restoration of the San Lorenzo River. These positions could be financed through grants from the U.S. Fish and Wildlife Service's Partnership for Amphibians, the National Oceanographic and Atmospheric Agency (NOAA), the California Coatal Commission (CCC), and the California Department of Fish and Game (CDFG), to name a few potential sources of funding.

The 2002 lower San Lorenzo River and Lagoon Managament Plan must be revised to provide specific amphibian and reptile restoration target criteria (Knutson et al. 1999). In terms of increasing reptile and amphibian numbers and diversity, the results of this study and review of other pertinent information leads me to make the following specific recommendations:

1. Install and maintain in-channel: native grasses, sedges, and rushes (Festuca sp., Carex sp., Juncus sp.), and nettle (Urtica sp.) (to deter human interference). Upslope woody species should include alder (Alnus sp.) and elderberry (Sambucus sp.).

2. Provide understory vegetation upslope where possible, including shrubs such as gooseberry (Ribes sp.) and low trees such as Western dogwood (Cornus sp.) and Western redbud (Cercis sp.). 
3. Be selective in thinning of woody plants for flood control--leave the alders.

4. Establish a minimum 50-m-wide riparian buffer, where possible, to retain stable moisture conditions and microhabitat needed for amphibians. This would involve more planting of natives along the outer slopes of the levees as well as on top of the levees. Planting a continuous buffer to the Sycamore Grove area north of the Water Street Bridge would connect the lower San Lorenzo River to source populations for recolonization of herpetofauna.

5. Bioengineer in-stream habitat to create pools, backwaters, and basking logs where feasible.

6. Use community groups to help revegetation and maintenance efforts. Create a part-time position for a volunteer coordinator.

7. Encourage UCSC and SJSU environmental studies students to participate in further studies.of habitat interactions for application of adaptive management strategies by San Lorenzo River ecologists. 


\section{BIBLIOGRAPHY}

Aubry, Keith B. and Patricia A. Hall. "Terrestrial Amphibian Communities in the Southern Washington Cascade Range," in Wildlife and vegetation of unmanaged Douglas-Fir Forests, L. F. Ruggeiro, K. B. Aubry, A. B. Carey, and M. H. Huff, technical coordinators (Portland, Ore.: Pacific Northwest Research Station, Forest Service, U.S. Department of Agriculture, 1991). Gen. Tech. Rep. PNW-285.

Blaustein, Andrew, David Wake, and Wayne Sousa. "Amphibian Declines: Judging Stability, Persistence, and Susceptibility of Populations to Local and Global Extinctions." Conservation Biology 8, no. 1 (1994): 60-71.

Block, William, Alan Franklin, James P. Ward, Jr., Joseph L. Ganey, and Gary C. White. "Design and Implementation of Monitoring Studies to Evaluate the Success of Ecological Restoration on Wildlife." Restoration Ecology 9, no. 3 (2001): 293.

Bodie, R. J. "Stream and Riparian Management for Freshwater Turtles." Journal of Environmental Management 62 (2001): 443-445.

Bodie, R. J. and Raymond D. Semlitsch. "Spatial and Temporal Use of Floodplain Habitats by Lentic and Lotic Species of Aquatic Turtles." Oecologia 122 (1999): 138-146.

Bowers, Catherine F., Hugh Hanlin, David C. Guyn, John P. McLendon, and James R. Davis. "Herpetofaunal and vegetational characterization of a thermally-impacted stream at the beginning of restoration." Ecological Engineering 15, suppl. 1 (2000): S101-14.

Bulger, John A., Roberta Smith, and Mark Hylkema. Scotts Creek Watershed Assessment (Unpublished file, 2004).

Bunn, Stuart E., and Peter M. Davies. "Biological Processes in Running Water and Their Implications for the Assessment of Ecological Integrity." Hydrobiologia 422/423 (2000): 61-70.

Cairns, John Jr. "Setting Ecological Restoration Goals for Technical Feasibility and Scientific Validity." Ecological Engineering 15 (2000): 171-180.

California State Water Resources Board. "The Status and Future of Bioassessment for California Streams." 2004. http://www.swrcb.ca.gov/swamp/doc/bioassess (May 2004). 
Cole, Elizabeth C., William McComb, Michael Newton, Carol Chambers, and J. P. Leeming. "Response of Amphibians to Clearcutting, Burning, and Glphosate Application in the Oregon Coast Range." Journal of Wildlife Management 61 (1997): 656-664.

Corn, P. S. and B. R. Bury. Sampling Methods for Terrestrial Amphibians and Reptiles (Portland, Ore.: Pacific Northwest Research Station, Forest Service, U.S. Department of Agriculture, 1990). Gen. Tech. Rep. PNW-GTR-256.

Cronin, John, and Robert F. Kennedy, Jr. The Riverkeepers: Two Activists Fight to Reclaim Our Environment as a Basic Human Right (New York: Scribner, 1997).

Davidson, Carlos, H. Bradley Shaffer, and Mark Jennings. "Spatial Tests of the Pesticide Drift, Habitat Destruction, UV-B, and Climate-Change Hypotheses for California Amphibian Declines." Conservation Biology 16, no. 6 (2002).

Drost, Charles A. and Gary M. Fellers. "Collapse of a Regional Frog Fauna in the Yosemite Area of the California Sierra Nevada, USA." Conservation Biology 10 (1996): 414-425.

Ehrenfeld, Joan. "Evaluating Wetlands within an Urban Context." Ecological Engineering 15 (2000), 253-265.

Erlich, Paul. "The Loss of Diversity: Causes and Consequences," in Biodiversity, ed. E. O. Wilson (Washington: National Academy Press, 1986).

Faber, Phyllis M. and Robert Holland. Common Riparian Plants of California: A Field Guide for the Layman (Mill Valley, Calif.: Pickleweed Press, 1996).

Gomez, M. and R. G. Anthony. "Amphibian and Reptile Abundance in Riparian and Upslope Areas of Five Forest Types in Western Oregon." Northwest Science 70, no. 2 (1996): 109-119.

Gore, Al. Earth in the Balance: Ecology and the Human Spirit (New York: Penguin, 1992).

Grayson, J. E., M. G. Chapman, and A. J. Underwood. "The Assessment of Restoration of Habitat in Urban Wetlands." Landscape and Urban Planning 43, no. 4 (1999): 227-236.

Hall, R. J. Effects of Environmental Contaminants on Reptiles: A Review (Laurel, Md.: Patuxent Wildlife Research Center, U.S. Fish and Wildlife Service, 1978). 
Heyer, W. R., M. A. Donnelly, R. W. McDiarmid, L. C. Hayek, and M. S. Foster. Measuring and Monitoring Biological Diversity: Standard Methods for Amphibians (Washington: Smithsonian Institution Press, 1994).

Jennings, Mark and Marc Hayes. Amphibian and Reptile Species of Special Concern in California, (Rancho Cordova, Calif.: Inland Fisheries Division, California Department of Fish and Game, 1994). Contract no. 8023.

. Amphibian and Reptile Species of Special Concern in

California, Final Report (Rancho Cordova, Calif.: Inland Fisheries Division, California Department of Fish and Game, 1996). Contract no. 8023.

Karr, J. R. "Biological integrity: A Long-Neglected Aspect of Water Resource Management." Ecological Applications 1 (1991): 66-84.

Karr, J. R. and E. W. Chu. Restoring Life in Running Waters--Better Biological Monitoring (Covelo, Calif.: Island Press, 1999).

Kentula, Mary E. "Perspectives on Setting Success Criteria for Wetland Restoration." Ecological Engineering 15 (2000): 199-209.

Knutson, Melinda G., John R. Sauer, Douglas A. Olsen, Michael J. Mossman, Lisa M. Hemesath, and Michael J. Lanoo. "Effects of Landscape Composition and Wetland Fragmentation on Frog and Toad Abundance and Species Richness in Iowa and Wisconsin, USA." Conservation Biology 13 (1999): 1437-46.

Lake, P. S. "On the Maturing of Restoration: Linking Ecological Research to Restoration." Ecological Management \& Restoration 2, no. 2 (2001): 110.

Laurance, William and Peter Kareiva. "In Briefs: Neotropical Amphibian Declines." Trends in Ecology \& Evolution 17, no. 4 (2002): 162-3.

Lind, Amy J. and Hartwell H. Welsh. "Ontogenetic Changes in Foraging Behaviour and Habitat Use by the Oregon Garter Snake, Thamnophis atratus hydrophilus." Animal Behavior 48 (1994): 1261-73.

MacArthur, R. H. and E. O. Wilson. The Theory of Island Biogeography (Princeton, N.J.: Princeton University Press, 1967).

MacClintock, L., R. F. Whitcomb, and B. L. Whitcomb. "Evidence for the Value of Corridors and Minimization of Isolation in Preservation of Biotic Diversity." American Birds 31 (1977):6-12. 
MacCracken, James. "Response of Forest Floor Vertebrates to Riparian Hardwood Conversion Along the Bear River, Southwest Washington." Forest Science 48 (2002): 299-308.

Miller, Jr., Tyler G. Living in the Environment: Principles, Connections, and Solutions (Pacific Grove, Calif.: Brooks/Cole Publishing Company, 2000).

Mitsch, William and James G. Gosselink. Wetlands (New York: John Wiley and Sons, 1993).

Mitsch, William and Renee F. Wilson. "Improving the Success of Wetland Creation and Restoration with Know-How, Time, and Self-Design.” Ecological Applications 2 (1996): 77.

Murphy, Dennis D. "Challenges to Biological Diversity in Urban Areas," in Biodiversity, E. O. Wilson, ed. (Washington: National Academy Press, 1986).

Parris, Kirsten and Michael McCarthy. "What Influences the Structure of Frog Assemblages at Forest Streams?" Australian Journal of Ecology 24 (1999), no. 5: 495.

Philip Williams and Associates, Mitchell Swanson, Elizabeth Bradley, Hohan Stanley and Associates, Kathleen Lyons, William Lapaz, David Suddjian, and Jerry Smith. The San Lorenzo River Enhancement Plan: A Plan for Biological Enhancement on the Lower San Lorenzo River (Santa Cruz: City of Santa Cruz, 1989).

Philip Williams and Associates. San Lorenzo Urban Renewal Plan (Santa Cruz: City of Santa Cruz, 2002).

Pough, Harvey E., R. M. Andrews, J. E. Cadle, M. L. Crump, A. H. Savitzky, and K. D. Wells. Herpetology, 3d edition (Upper Saddle River, N.J.: Pearson Prentice Hall, 2004).

Risser, Paul G. "Biodiversity and Ecosystem Function," in Ecosystem Management: Selected Readings, F. Samson and F. Knopf, eds. (Ann Arbor, Mich.: Edward Brothers, 1995).

Roessler, Cindy. Lower Coyote Creek Flood Control Project Report of Mitigation and Monitoring Programs, 1996-1998 (Santa Clara, Calif.: Santa Clara Valley Water District, 1999). 
Rowley, Mathers. Director, Scotts Creek Watershed Council, Swanton, Calif. Personal communications (2003).

Simberloff, Daniel, James A. Farr, James Cox, and David W. Mehlman. "Movement Corridors: Conservation Bargains or Poor Investments?" Conservation Biology 6 (1992): 493.

Simenstad, Charles A. and Jefferey R. Cordell. "Ecological Assessment Criteria for Restoring Anadromous Salmonid Habitat in Pacific Northwest Estuaries." Ecological Engineering 15 (2000): 283-302.

Simon, Thomas, P. "The Use of Biological Criteria as a Tool for Water Resource Management." Environmental Science \& Policy 3 (2000): S43-9.

Singer, Steven. San Lorenzo River Watershed Management Plan: Vegetation and Wildlife Technical Section (Santa Cruz, Calif: Community Resources Agency, Watershed Management Section and State of California Resources Agency; Department of Fish and Game, Protected Waterways Program, 1979).

Smith, Jerry, Ph.D. Wildlife Biologist and Professor, San Jose State University, San Jose, Calif. Personal communications (January-May 2003).

Swanson Hydrology and Geomorphology, Native Vegetation Network, and Hagar Environmental Science. Lower San Lorenzo River and Lagoon Management Plan (Santa Cruz: City of Santa Cruz Redevelopment Agency, 2002).

Thom, Ronald M. "Adaptive Management of Coastal Ecosystem Restoration Projects." Ecological Engineering 15 (2000): 354-372.

U.S. Environmental Protection Agency. "Bioindicators of Watershed Health: Biological Integrity." 2004. http://www.epa.gov/bioindicators/html/biointeg.html (May 2004).

U.S. Fish and Wildlife Service. Recovery Plan for the California Red-Legged Frog (Rana aurora draytonii) (Portland, Ore.: U.S. Fish and Wildlife Service, 2002).

Vander Zanden, M. Jake, Julian D. Olden, and Claudio Gratton. "Food-Web Approaches in Restoration Ecology," in Foundations of Restoration Ecology: Society for Ecological Restoration International, Donald Falk, Margaret Palmer, and Joy Zedler, eds. (Washington: Island Press, 2006). 
Vesely, David G. and William McComb. "Salamander Abundance and Amphibian Species Richness in Riparian Buffer Strips in the Oregon Coast Range." Forest Science 48 (2002): 291-7.

Welsh, Hartwell and Amy Lind. "Multiscale Habitat Relationships of Stream Amphibians in the Klamath-Siskiyou Region of California and Oregon." Journal of Wildlife Management 66 (2002): 581-599.

Welsh, Hartwell and Lisa Ollivier. "Stream Amphibians as Indicators of Ecosystem Stress: A Case Study from California's Redwoods." Ecological Applications 4 (1998): 1118-32.

West, Terry L., Lisa M. Clough, and William G. Ambrose, Jr. "Assessment of Function in an Oligohaline Environment: Lessons Learned by Comparing Created and Natural Habitats." Ecological Engineering 15 (2000): 302-21.

Wilcox, Bruce A. and Dennis D. Murphy. "Conservation Strategy: The Effect of Fragmentation on Extinction." American Naturalist 125 (1984): 879.

Wilkins, Neal R. and Phil N. Peterson. "Factors Related to Amphibian Occurrence and Abundance in Headwater Streams Draining Second-Growth Douglas Fir Forests in Southwestern Washington." Forest Ecology and Management 139 (2000): 79 91.

Wilson, E. O. "The Current State of Biological Diversity," in Biodiversity, E. O. Wilson, ed. (Washington: National Academy Press, 1986).

Zedler, Joy B. and John C. Callaway. "Evaluating the Progress of Engineered Tidal Wetlands." Ecological Engineering 15 (2000): 211-25. 


\section{APPENDIX A}

\section{PARTIAL SPECIES LIST OF NATIVE VEGETATION IN STUDY SITE AT SCOTTS CREEK, CALIFORNIA}

California aster . ............

California sage ............

Mugwort

Figwort

Buttercup

Thimbleberry

Western Goldenrod

American water horehound.

Calf lotus

Coast bush lupine

California poppy.

Coast twinberry

California gooseberry

California blackberry

Coffeeberry

Spreading rush

Bull tule

Cattail

Sedges

Nut sedge

Salmonberry

Tanbark oak

Coast Live oak ...

California buckeye ...........

Creek dogwood

White alder

Black cottonwood

Willow species .

California redwood.

Box elder
Aster chilensis

Artemesia californica Artemesia douglasii Schrophularia atrata

Ranunculus orthorhynchus

Rubus velutinus

Euthamia occidentalis

Lycopus americanus

Lotus wrangelianus

Lupinus arboreus

Eschscholzia californica

Lonicera involucrate

Ribes californicus

Rubus ursinus

Rhamnus californica

Juncus patens

Scirpus robustus

Typha angustifolia

Cares sp.

Cyperus esulentis

Rubus spectabilis

Lithocarpus densiflorus

Quercus aggrifolia

Aesculus californica

Cornus californica

Alnus rhombifolia

Populus tricocarpa

Salix sp.

Sequoia sempervirens

Acer negundo 


\title{
APPENDIX B \\ PARTIAL SPECIES LIST OF NATIVE PLANTS USED IN LANDSCAPING OF SAN LORENZO RIVER LEVEES
}

\author{
California blackberry .......... Rubus ursinus \\ Coffeeberry .............. Rhamnus californica \\ Wild rose ............... Rosa californica \\ California gooseberry.......... Ribes californicus \\ California sycamore.......... Platenus racemosa \\ Black cottonwood ............ Populus tricocarpa \\ Box elder ................ Acer negundo \\ Sky lupine .............. Lunpinus nanus \\ Western goldenrod .......... Euthamia occidentalis \\ Willow species.............. Salix sp. \\ Creeping wild rye grass ......... Leymus tricocarpa
}




\section{APPENDIX C \\ SPECIES LIST OF REPTILES AND AMPHIBIANS \\ OF SCOTTS CREEK}

Reptiles

Northwestern fence lizard....... Sceloporous occidentalis occidentalis

Western skink ............ Eumeces skiltonianus skiltonianus

Southern alligator lizard ........ Gerrhonotus multicarinatus multicarinatus

Northern alligator lizard ........ Gerrhonotus coerulus coerulus

Pacific Rubber boa ........... Charina bottae bottae

Pacific ringneck snake ........ Diadophos punctatus amabilis

Sharp-tailed snake ........... Contia tenuis

Western yellow-bellied racer. ..... Coluber constrictor mormon

Pacific gopher snake ......... Pituophis melanoleucus catenifer

Coast garter snake ......... Thamnophis elegans terrestris

Santa Cruz garter snake ........ Thamnophis couchi atratus

Northern Pacific rattelsnake ...... Crotalus viridis oreganus

Amphibians

California giant salamander. ..... . Dicamptadon ensalus

California newt ........... Taricha torosa torosa

Rough-skinned newt ......... Taricha granulosa

Monterey salamander ......... Ensatina eschscholtzii spp.

California slender salamander.... . Batrachoseps attenuatus

Black salamander ........... Aneides flavipuntus

Arboreal salamander........... Aneides lugubris

Pacific treefrog ............ Hyla regilla

California red-legged frog. ...... Rana aurora draytonii

Bullfrog .............. Rana catebensiana

(Bulger, Smith, and Hylkema 2004) 